\title{
Effects of cardiopulmonary bypass on the accuracy of non-invasive hemoglobin measurement by pulse co-oximetry
}

\author{
K Tokuda $^{1 *}$, K Yamaura $^{2,3}$, M Higashi $^{3}$, S Hoka $^{3}$ \\ From ESICM LIVES 2015 \\ Berlin, Germany. 3-7 October 2015
}

\section{Introduction}

A non-invasive continuous measurement of hemoglobin (Hb) by pulse co-oximetry $(\mathrm{SpHb})$ using Radical- $7^{\circledR}$ (Masimo Corporation, CA, USA) is a newly developed method of measuring total $\mathrm{Hb}$ concentration. Previously, the accuracy of $\mathrm{SpHb}$ in clinical settings was reported (1). However, it has been also reported that $\mathrm{SpHb}$ has poor correlation with arterial $\mathrm{Hb}$ after cardiac surgery (2). Here we examined the accuracy of $\mathrm{SpHb}$ measured by New Radical- $7^{\circledR}$, which has new software version for measurement of total $\mathrm{Hb}$, in cardiac surgery patients using cardiopulmonary bypass (CPB).

\section{Methods}

Forty-six patients undergoing cardiac surgery using hypothermic $\mathrm{CPB}$ were included in this prospective study. Along with routine monitors, $\mathrm{SpHb}$ and direct radial arterial blood pressure were monitored. Arterial $\mathrm{Hb}$ by co-oximeter (Radiometer ABL 850; Radiometer, Copenhagen, Denmark) and $\mathrm{SpHb}$ with a new sensor (Revision K) for $\mathrm{SpHb}$ were simultaneously obtained and analyzed as paired data. SpHb was adjusted by "in vivo calibration" at start of operation, after $\mathrm{CPB}$, and at transfer into the ICU. The data were shown as mean \pm SD. Coefficient and Bland-Altmann analysis were used for analysis. Comparison of the mean differences was analyzed by Student's t-test with Bonferroni correction. $P$ value $<0.05$ was considered statistically significant.

\section{Results}

A total of 386 time-matched $\mathrm{SpHb}$ and arterial $\mathrm{Hb}$ (before $\mathrm{CPB}$ in 67 pairs, after $\mathrm{CPB}$ in 81 pairs, and at transfer into the ICU in 238 pairs) were analyzed. SpHb ranged from 6.9 to $16.6 \mathrm{~g} / \mathrm{dl}$. The correlation coefficient was 0.87 before $\mathrm{CPB}, 0.61$ after $\mathrm{CPB}$ and 0.72 in the ICU. The mean difference ( $\mathrm{SpHb}$ - arterial $\mathrm{Hb}$ : bias) was $0.34 \mathrm{~g} / \mathrm{dl}$ before CPB, $-0.12 \mathrm{~g} / \mathrm{dl}$ after CPB, and $-0.19 \mathrm{~g} / \mathrm{dl}$ in the ICU with 1SD for the bias $1.03 \mathrm{~g} / \mathrm{dl}, 0.86 \mathrm{~g} / \mathrm{dl}$, and $1.11 \mathrm{~g} / \mathrm{dl}$, respectively. The correlation and mean difference between $\mathrm{SpHb}$ and arterial $\mathrm{Hb}$ showed good correlation before $\mathrm{CPB}$ when perfusion index was over 1.4. However, the correlation and mean difference between $\mathrm{SpHb}$ and arterial $\mathrm{Hb}$ after $\mathrm{CPB}$ and in the ICU did not show significant differences whether or not perfusion index was over 1.4.

\section{Conclusions}

Our study showed that SpHb measured by New Radical $-7^{\circledR}$ deviated from arterial $\mathrm{Hb}$ measured by Radiometer ABL850 ${ }^{\circledR}$ after CPB; the difference did not depend on peripheral perfusion evaluated with perfusion index. These results suggest that some factors except for peripheral perfusion may decrease the accuracy of SpHb after CPB. Although non-invasive continuous $\mathrm{Hb}$ measurement by pulse co-oximetry is clinically useful in operating theater (3) and intensive care unit (4), actual $\mathrm{Hb}$ measurement of blood samples may remain to be needed after cardiac surgery using $\mathrm{CPB}$.

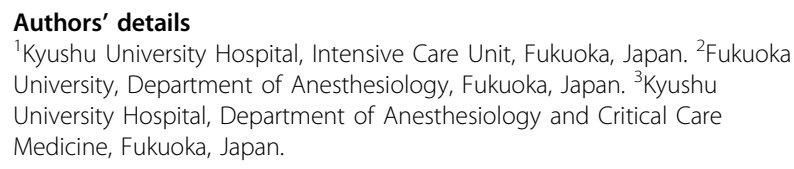

Published: 1 October 2015 


\section{References}

1. Anesth Analg 2010, 111:1424-6.

2. Anesth Analg 2011, 113:1052-7.

3. Anesthesiology 2012, 116:65-72.

4. Critical Care Med 2011, 39:2277-82.

doi:10.1186/2197-425X-3-S1-A745

Cite this article as: Tokuda et al.: Effects of cardiopulmonary bypass on

the accuracy of non-invasive hemoglobin measurement by pulse

co-oximetry. Intensive Care Medicine Experimental 2015 3(Suppl 1):A745.

\section{Submit your manuscript to a SpringerOpen ${ }^{\circ}$ journal and benefit from:}

- Convenient online submission

- Rigorous peer review

- Immediate publication on acceptance

- Open access: articles freely available online

- High visibility within the field

- Retaining the copyright to your article

Submit your next manuscript at $\gg$ springeropen.com 